\title{
KEBANGKITAN AGAMA DAN PRASANGKA SEKULER DALAM KAJIAN HUBUNGAN INTERNASIONAL
}

\author{
Achmad Djatmiko \\ Pusdiklat Kementerian Luar Negeri
}

\begin{abstract}
The global resurgence of religion seems nowadays to generate repression as it tends to create international instability, political upheaval and chaotic states. Most political scientist and intelligence experts did not predict the resurgence because it was not supposed to happen in a country participating so thoroughly in modernization and Westernization.

It is interesting to learn that so many scholars and policymakers who monitored the international politics have missed the warning signs about the resurgence. It because of the argument that religion was the object that needed to vanish for modern international politics to come into being. Religion has been, and largely remains, what the discipline of International Relations (IR) can speak about only as a threat to its own existence.

This paper tries to explain how the resurgence of religion has been on the spotlight in the eyes of IR Study. It also explains that the IR Study now faces a serious dilemma to treat religion in such a proper way. Various arguments on the strategy to deal with religion has come up that makes religion a more and more interesting subject in academic realms.
\end{abstract}

Kata Kunci: Kebangkitan agama, modernisasi, pencerahan, sekularisasi, Westphalia

\section{A. PENDAHULUAN}

Selama lebih dari dua dasawarsa terakhir kajian Hubungan Internasional (HI) dihadapkan pada fenomena global kebangkitan kembali agama (global resurgence). Fenomena ini menjadi tantangan tersendiri bagi logika sekularisme yang telah mendominasi kajian HI. Bagaimana memperoleh formula yang tepat untuk menyertakan keberadaan agama menjadi salah satu variable penting dalam kajian HI merupakan perhatian utama yang akhirnya mendatangkan dilema tersendiri. Bahkan, terdapat spekulasi kemungkinan perlunya merumuskan suatu paradigm baru, misalnya semacam 'peradaban yang berakar pada agama" (religiously rooted civilizations)?

Dalam tradisi kajian HI, dan juga ilmu sosial pada umumnya, agama memang tidak penah mendapatkan perhatian sebagai faktor penting ataupun variable analisis karena dianggap tidak memiliki peran dan dampak terhadap kehidupan masyarakat apalagi hubungan antar negara. Ini dapat difahami karena para pakar ilmu sosial dan filsuf terkemuka dunia Barat di Abad ke-18 hingga awal Abad ke-20 seperti Comte, Durkheim, Freud, Marx, Nietzsche, Voltaire dan Weber, telah memberikan pengaruh besar terhadap perkembangan ilmu sosial, dengan kesamaan pandangan bahwa 
hadirnya masa Pencerahan (enlightenment) akan memusnahkan agama sebagai landasan pemikiran dan pengaturan dunia

Pandangan bahwa "Tuhan telah mati" (God is dead), yang didengungkan Nietzsche misalnya, merujuk pada hilangnya kepercayaan kristiani dan komitmennya terhadap keberadaan kekuasaan mutlak. Demikian halnya, Weber berkeyakinan bahwa ideologi sekuler terus bergerak menggantikan agama sebagai dasar legitimasi and pengawasan sosial di masyarakat Abad ke-19. Secara umum para ahli dan filosof sosial Barat tersebut tidak mengakui adanya agama sebagai landasan penjelasan terhadap hal ikhwal duniawi karena sangat percaya bahwa di sebuah masyarakat industri yang modern yang lebih diperlukan adalah rasionalitas, sikap ilmiah dan legalitas, untuk dapat memahami dan mengatur kehidupan dunia ini.

Ketika kini agama banyak diperbincangkan, temanya lebih banyak pada pembahasan aspek historis, yang lebih sebagai penjelasan dan pemberian alasan mengapa agama 'terlewatkan' dalam kajian. Selain itu, dari berbagai perbincangan mengenai kebangkitan agama ini, juga terungkap tingginya tingkat kesulitan yang dihadapi para pakar HI untuk mendefinisikan agama sehingga dapat memenuhi persyaratan menjadi salah satu variable dan bahasan pokok dalam kajian.

Tulisan singkat ini mencoba memaparkan mengenai fenomena kebangkitan agama secara global sehingga menjadi tantangan bagi kajian HI, problematika teoritis dalam mengidentifikasi agama dan tantangan kajian HI di masa depan.

\section{Fenomena Kebangkitan Agama}

Realitas menunjukkan bahwa peran agama kini tidak dapat lagi disembunyikan karena karakternya yang lintas batas dan kawasan, merambah ke seluruh penjuru dunia. Bahkan, dalam hal tertentu, perannya justeru terkesan semakin dominan. HI kini menghadapi masalah untuk mempertimbangkan keberadaan peran agama ini di dalam suatu lingkup kajian yang beraliran sekularisme yang dominan. Hal ini dapat diibaratkan seperti menyambut kehadiran tamu asing yang selama ini sangat dibenci meskipun sosoknya belum benar-benar dimengerti, hanya berdasarkan praduga.

Kendala yang dihadapi kajian HI dalam menghadapi kebangkitan agama, antara lain, adalah: Pertama, agama belum dikenal secara material akibat telah dimarginalkan dan ditempatkan sebagai 'makhluk asing' sebelumnya. Agama terlanjur dihilangkan dari wacana publik HI karena dianggap sebagai bagian dari tradisi masa lalu, milik masyarakat pra-modern yang keberadaanya lebih terkait dengan masalah domestik dan berdimensi personal. Kedua, agama diibaratkan seperti bangkit dari kubur, karena dalam kalkulasi pandangan sekularisme, ia semestinya lambat laun musnah dan kini semestinya sudah berada dalam fase hampir musnah seiring bergulirnya modernisasi, industrialisasi dan demokrasi serta rasionalitas dalam masyarakat.

Apakah agama akan terus dikesampingkan ataukah disambut sebagai objek kajian baru dalam HI? Untuk mengesampingkan agama dari kajian HI bukanlah hal mudah karena memerlukan alasan rasional, ilmiah dan akurat serta kontekstual sesuai realitas politik global. Sebaliknya, menambahkan agama sebagai topik kajian pun tidak mudah mengingat hal ini bertentangan dengan prinsip dasar dan eksistensi 
teori sekularisasi mereka, bahwa agama lambat-laun akan lenyap akibat tergerus oleh arus modernisasi di masyarakat. Antara bangkitnya kembali agama dalam realitas politik global dan keberadaan HI berfaham sekuler yang menampik kehadiran agama menjadi tema sentral perdebatan di kalangan para pakar HI saat ini.

Selama dasawarsa terakhir, semakin terlihat menjamurnya bahasan mengenai kebangkitan politis agama. Munculnya era post-positivist di tahun 1990an, telah membuka kesempatan bagi ilmu sosial dan HI untuk melakukan pembahasan terhadap tata nilai dan kejadian-kejadian yang tidak kasat mata, seperti halnya agama. Para pakar pun kemudian mulai mempelajari dampak positif apakah yang ditimbulkan oleh agama dalam proses modernisasi, demokratisasi dan penciptaan perdamaian, baik dalam konteks Barat maupun non-Barat. Selain itu juga melihat implikasi teoritis yang lebih mendalam dari kebangkitan global agama ini dalam melahirkan pemikiran mengenai masa depan ketertiban dunia.

Agenda penelitian terhadap hal ini, kemudian harus berhadapan langsung dengan konteks nyata yang sangat dibayangi oleh peristiwa traumatis Serangan "11 September 2001" dan perkembangannya. Konteks '11 September' seakan memperkuat pandangan kaum sekuler bahwa agama selalu berkaitan dengan instabilitas politik, negara yang kacau dalam ranah interaksi global, fundamentalisme dan terorisme. Arus utama pandangan publik di kalangan akademisi semakin merefleksikan keyakinan bahwa kembalinya agama dalam politik internasional utamanya dalam bentuk militansi dan kekerasan politik, dan semakin berkembangnya irasionalitas dalam sistem internasional yang berlangsung rasional.

Berbagai peristiwa terkait peran agama yang terpampang diibaratkan secara sinis seperti sebuah wabah yang dikirim Tuhan atau hukuman terhadap kehidupan duniawi. Seolah 'pembalasan' Tuhan kini mulai bermunculan. Karenanya, kemudian terdapat pandangan perlu munculnya paradigm baru sebagaimana halnya 'clash of civilization', munculnya fundamentalisme agamis atau konflik terhadap pandangan sekularisme'. Pada saat bersamaan, beberapa pakar menyadari adanya aspek positif dari manifestasi agama untuk dapat disandingkan dengan pendekatan sekuler tradisional dan bagaimana mereka dapat diintegrasikan dalam suatu kerangka analisis yang ada.

Kesadaran ini, meski belum disepakati oleh para pakar HI, namun telah menarik perhatian para pembuat kebijakan, pejabat negara dan praktisi. Seperti dikatakan Elizabeth Hurd, terdapat asumsi dasar bahwa sebenarnya para aktor dan penganut agamis telah terintegrasi dan bersinergi dalam teori dan praktek hubungan internasional. Masalah-masalah yang terkait dengan agama, misalnya, dengan segera akan dapat terselesaikan bila melibatkan para tokoh dan ahli agama sehingga terdapat potensi agama untuk berkontribusi terhadap masa depan dunia yang lebih baik yang tidak mustahil bisa diraih.

Meskipun demikian, pendekatan problem-solving semacam in sering gagal untuk menggambarkan esensi sesungguhnya dari peran agama dalam kehidupan publik internasional dan bentuk-bentuk pengetahuan yang menyertainya. Dalam konsep agama, terdapat jaringan kekuatan yang rumit, termasuk negara, pasar, kelembagaan, organisasai internasional, yang bersinergi untuk merumuskan suatu 
tatanan praktis yang dapat diterima, yang bernuansa toleran. Terkait hal ini, Hurd mengingatkan bahwa "sekularisasi bukanlah ketiadaan agama, tetapi kekuasaan untuk mendefinisikan, membentuk bahkan mengalihkannya. Itu adalah kekuatan untuk mempertegas identitas dan komunitas agama, memberikan sanksi terhadap kemapanan otoritas dan memberikan pressure terhadap situasi sehingga agama mendapat ruangan untuk berkembang.

Kembali ke peristiwa "Serangan 11 September" di AS, para ilmuwan terkesan sangat lamban untuk mengakui kebangkitan agama, khususnya menyangkut kawasan di luar Eropa, dan juga dalam mempertimbangkan bahwa agama telah membentuk dunianya sendiri. Agama pun memberi peran terhadap kebijakan polugri suatu negara. Seperti dikatakan Timothy Shah, "religion has become one of the most influential factors in world affairs in the last generation but remains one of the least examined factors in the professional study and practice of world affairs." bahwa agama telah menjadi salah satu faktor yang sangat berpengaruh pada generasi terakhir ini namun tetap merupakan salah satu faktor yang kurang diamati dalam kajian dan praktek professional menyangkut masalah-masalah global. Pangkal semua ini, sekali lagi, terletak pada dominasi sekularisasi, yang berpandangan bahwa ketika dunia mengalami modernisasi, agama akan memudar (wither away), seperti disebutkan oleh Marx dalam ilmu sosial kontemporer, termasuk HI.

Dari beberapa literatur mengenai agama dan politik global, belum didapatkan kesepakatan ataupun strategi teoritis yang mapan dan untuk memahami keberadaan agama. Seperti dikatakan Monica Dyffy Toft, "traditional international relations theory provides little guidance for those needing to understand the interplay of religion and politics in a global setting" Sangat disayangkan bahwa perkembangan konseptual dan teoriti saat ini pun tetap masih berada pada tataran yang sama, agama diposisikan terkucil dalam kajian HI. Sementara unsur-unsur sekularisasi tetap bercokol dengan pengaruhnya, terlihat kenyataan bahwa secara internal pandangan mereka sebenarnya tidak konsisten. Di hampir seluruh belahan dunia, dan hampir sepanjang keberadaan sejarah, penetrasi agama sangat dirasakan sehingga kebangkitannya kembali yang dihebohkan sekarang ini lebih tepat disebut sebagai kembali dari tempat pengasingannya.

Sikap para pakar HI yang demikian sebenarnya telah salah jalan. Peran yang dimainkan agama dalam HI tidaklah sesederhana yang diduga dan dianggap homogen. Agama sebenarnya telah memberikan pengaruh terhadap berbagai aspek HI melalui beragam cara. Salah satu pengaruh agama yang dapat diketahui pasti adalah sebagai sumber letigimasi. Nilai-nilai normatif, termasuk agama, selama ini diakui memainkan peran penting yang dapat digunakan oleh para praktisi di tingkat global, termasuk para pembuat kebijakan tradisional dan bahkan oleh para lawannya sekalipun, baik di luar maupun dalam negeri. Hal ini harus menjadi perhatian mengingat peran pentingnya terus meningkat.

Meskipun demikian, manifestasi pengaruh agama tidaklah hanya sebatas memberikan legitimasi terhadap suatu kebijakan yang sebenarnya juga memiliki motivasi non-agamis (secular). Seringkali bahkan, antara motivasi agamis dan sekuler bersinergi dan bertemu. Sebuah negara, misalnya, memiliki alasan politis untuk memberikan bantuan kepada pihak-pihak yang membutuhkan. Hal ini tentu saja sejalan dengan prinsip beramal baik kepada sesama yang dimiliki hampir semua 
agama, sebagai suatu kebajikan. Sama juga, kebijakan beberapa negara terhadap Israel, dalam banyak hal, termotivasi oleh kepentingan material di Timur Tengah, paling tidak untuk Amerika Serikat, serta kepentingannya dalam mendukung demokrasi dan sistem pasar bebas ke seluruh belahan dunia. Bisakah kita mengatakan bahwa kebijakan terhadap Israel tidak terkait dengan konflik kepentingan agama atas tempat-tempat suci yang menjadi sumber konflik agama?.

Jadi, kebijakan luar negeri suatu negara dapat juga dilatarbelakangi oleh aspek agama. Dapat terjadi bahwa pandangan agamis para penguasa dan pembuat kebijakan pun berperan, baik secara individual dalam suatu pemerintahan sekuler atau pun pemerintahan agamis seperti di Iran. Di lain pihak, kebijakan luar negeri dapat dipengaruhi oleh pandangan agamis dari penduduknya dalam suatu negara meskipun terkadang bertentangan dengan pandangan para penguasa. Kembali ke kasus Israel, misalnya, baik kaum Yahudi maupun Palestina meyakini bahwa tempat Haram esh-Sharif dimana Masjidil Aqsa berada adalah tempat suci yang tidak boleh diserahkan kepada pihak lawan. Pemimpin Israel maupun Palestina yang menyerah atas kasus ini meski dengan penyelesaian damai, sangat mungkin dapat kehilangan kepercayaan di mata rakyatnya.

Kendala lain menyangkut kebangkitan agama dalam kajian HI terkait dengan problematika definisi agama. Seperti telah disinggung di muka, dari berbagai perbincangan mengenai kebangkitan agama ini, juga terungkap tingginya tingkat kesulitan yang dihadapi para pakar HI untuk mendefinisikan agama sehingga dapat memenuhi persyaratan menjadi salah satu variable dan bahasan pokok dalam kajian. Kelemahan metode dalam mengkaji agama menjadi penyebabnya yang telah dimulai sejak abad ke-18. Kajian terhadap agama dihadapkan pada masalah definisi yang belum disepakati, yang akhirnya menjadi semakin kompleks dengan munculnya kelompok filosofis-humanis di Eropa Barat yang menolak halo-hal terkait supranatural.

Pandangan para humanis sekuler memiliki pengaruh kuat di dunia Barat dan diikuti oleh para ahli, yang kemudian mencoba mendefinisikan kembali agama sehingga mencakup juga unsur humanis filosofis. Akibatnya, pertanyaan mengenai definisi agama sampai kini belum terjawab tuntas dan tetap menjadi bahan perbincangan. Kemudian muncul lah pertanyaan yang sangat mendasar menyangkut: a) Apakah agama harus didefinisikan? dan 2) Jika demikian, bagaimana caranya?.

TIdak dapat dielakkan bahwa beragam definisi yang ada perlu dikaji kembali disertai perkiraan dan dampak yang timbul dari setiap definisi tersebut. Idealnya, dari beragam definisi yang tersedia dapat ditentukan definisi mana yang paling berguna dalam kajian mengenai fenomena agama. Yang terjadi tidaklah demikian. Pembahasan mengenai definisi agama cenderung tidak memuaskan karena semua definisi yang telah tersedia dianggap belum layak digunakan sebagai pedoman untuk disepakati bersama.

Terkait hal ini, Robert Baird melihat bahwa hampir semua sejarahwan agama memiliki anggapan yang salah dengan pendapatnya bahwa agama merupakan sebuah kata yang berhubungan dengan "sesuatu di luar sana yang esensinya hanya dapat difahami oleh para sejarahwan agama" Pandangan lain disuarakan oleh Pummer yang mengatakan bahwa untuk mendefinisikan agama sebagai sesuatu yang 
'sakral" menyiratkan suatu pemahaman teologis dan ontologis, akibat belum ditemukannya pemahaman yang benar.

Terdapat dua jenis definisi agama sejauh ini, yang setidaknyha dapat dijadikan pegangan sementara mengenai agama. Pembahasan mengenai definisi, haruslah mempertimbangkan keberadaan dua jenis ini, yaitu definisi substantive dan fungsional. Definisi substantive menyangkut nilai dan pemikiran agamis, yang mencakup di dalamnya definisi terkait supranatural dan makhluk manusia super. Adapun definisi fungsional adalah definisi agama dalam kaitannya dengan konsekuensi ataupun fungsinya dalam diri manusia, masyarakat, kebudayaan umumnya.

Keunggulan definisi fungsional ini adalah bahwa dapat diterapkan secara seimbang baik terhadap system kepercayaan ketuhanan ataupun non-ketuhanan, di masyarakat yang mengakui adanya kekuatan supranatural. Dengan definisi ini bias diamati perubahan dan ketidak-sinambungan sejarah secara lebih baik, dan juga bias digabungkan ke dalam penelitian dan kajian empiris sehingga dapat dibuktikan kebenarannya.

\section{Prasangka Sekuler}

Apakah sekularisme? Pada umumnya disepakati bahwa sekularisme mendukung adanya pemisahan poltik dan agama. Teori sekularisma selalu dihadapkan pada tantangan untuk menjawab sedikitnya tiga pertanyaan: Pertama, bisakah pemisahan antara politik dan agama dilakukan. Kedua, apakah alasan yang membenarkan pemisahan agama dan politik itu? Ketiga, setelah pemisahan, bagaimanakah hubungan antara keduanya dapat dilihat?

Sekularisasi berpandangan bahwa "agama akan semakin tidak penting di dunia ini ("religion is becoming less important in the world."), dan itu diyakini merupakan konsekuensi logis dari modernitas. Faham sekularisme meyakini bahwa modernisasi merupakan mesin penggerak utama dalam menyingkirkan dan menggiring para "tuhan" menuju masa pensiun.

Ada tiga prinsip dasar sekularisasi, yaitu 1) mempertahankan konsep mengenai adanya kesenjangan besar antara dunia "agamis" dan "sekuler", 2) Hal-hal terkait agama berada dalam lingkup pribadi (private sphere), dan 3) Privatisasi agama merupakan "sine qua non" (keharusan) dalam system demokrasi liberal Selain itu, sebagaimana dikatakan Jose Cassanova, sekularisasi mengandung 3 konotasi dengan pengertian yang berbeda satu dengan yang lain, yaitu:

a)Sekularisasi diartikan sebagai menurunnya kepercayaan dan praktek peribadatan agama di masyarakat modern, sehingga sering diartikan sebagai bagian dari proses pembangunan manusia secara universal. Konotasi ini paling sering digunakan sebagai bahan perdebatan saat ini.

b) Sekularisasi merupakan privatisasi agama, sering difahami sebagai konsekuensi dari kecenderungan sejarah modern yang bersifat normatif, yang sesungguhnya menjadi prakondisi bagi politik demokrasi lliberal modern; dan

c) Diferensiasi dalam ranah sekuler (negara, ekonomi dan iptek), biasanya difahami sebagai 'emansipasi' dari norma-norma dan pranata agama. Konotasi ini 
merupakan komponen inti dari teori sekularisasi klasik, yang berhubungan dengan makna historis-etimologis asli dan istilah Kekristenan abad pertengahan. Ia merujuk pada transformasi makna, baik menyangkut benda atau pun orang, dari kepemilikan atau pengendalian yang bersifat agamis atau gerejawi kepada sipil dan duniawi

Pandangan sekularisasi sangat menonjol dalam kajian ilmu sosial di Eropa dan Amerika, sehingga kemudian secara khusus sangat mendominasi kajian HI. Alasannya sangat jelas, karena kajian ini mendasarkan pada prinsip "penolakan terhadap agama" pasca perjanjian Westphalia 1648 dan tetap bertahan hingga sekarang. Seperti dikatakan Jack Snyder, "sifat dasar teori HI yang menonjol dalam melaksanakan kajian empirisnya adalah sama sekali tidak menyentuh agama. Daniel Philpott menyuarakan pendapat senada bahwa "Teori-teori utama kajian HI memang menekankan bahwa negara bangsa (nation-state), organisasi internasional, partai politik (political parties), klas sosial, bisnis, kepentingan, kelompok, NGOS maupun para pe-lobby yang mengejar tujuan kepentingan politik, dengan melibatkan kekuasaan (power), penaklukan (conquest), kebebasan (freedom), kemakmuran (wealth), kesejahteraan (welfare provision), HAM, keadilan (justice), kebersihan lingkungan (environmental cleanliness) maupun tujuan lainnya. Dari semua itu, tidak satu pun yang mengandung tujuan agamis dan tidak mempertimbangkan kemungkinan adanya keterlibatan dan pengaruh tokoh ataupun kelompok agamis terhadapnya. Dasar dari sikap ini dapat dijelaskan dengan sudut pandang intelektual dan aspek sejarah.

Secara intelektual, pandangan sinis faham era Pencerahan (Age of Enlightenment) telah mempengaruhi pemikiran beberapa pakar ilmu sosial modern di abad ke-19. Bahwa pada dasarnya kecenderungan untuk mengesampingkan agama dapat dirunut pada pola pemikiran dalam karya Weber, Durkheim dan Marx. Ketiganya percaya bahwa agama merupakan peninggalan era pra-modern, ditakdirkan untuk lenyap sejalan dengan meningkatnya gerakan industrialisasi, urbanisasi, birokratisasi dan rasionalisasi. Pandangan semacam ini kemudian dipadukan dengan kajian ilmu politik yang berkembang di abad ke-19. Dari sudut pandang kajian HI, kaenanya, tinjauan mengenai agama dianggap bertentangan dengan kajian perbandingan politik. Problematika ini diperburuk oleh kenyataan bahwa mereka yang menjalankan agenda riset terhadap disiplin HI pada umumnya tidak menyertakan agama dan tidak perduli terhadapnya.

Adapun secara historis, pengalaman reformasi yang telah menghasilkan perang agama yang berlangsung selama lebih dari 30 tahun di kawasan Eropa menjadi peringatan (warning) mengenai bahaya keberadaan agama bila melampaui batasan wilayah pribadi. Sejalan dengan ini, Philpott beranggapan bahwa pandangan konvensional terhadap kenyataan tersebut adalah, "Perang agama dan wilayah kedaulatan merupakan prinsip politik utama Eropa selama lebih dari seabad, yang kemudian dapat diakhiri setelah adanya perjanjian Westphalia.

Terhadap hal demikian, seorang teolog, William Cavanaugh menyimpulkan bahwa agama merupakan sumber konflik internasional, sebagai "the creation myth for modernity". Dan dalam konteks tersebut, lahirnya Islam politik telah memberdayakan kembali sekularisme di Barat. Beralasan kiranya bila Elizabeth Hurd mengatakan bahwa "Lebih dari agama manapun atau tradisi politik manapun, 
Islam telah hadir mewakili kaum 'non-sekuler' dalam pemikiran dan praktek politik di Eropa dan Amerika. Sekularisme lalu berkolaborasi sebagai bagian dari oposisi terhadap ide anti-modern, anti-Kristen dan Teokrasi Islam Timur Tengah"

Dalam kajian HI diyakini bahwa sekularisasi (privatisasi dan marginalisasi kepercayaan agama) adalah senjata utama untuk merealisasikan lahirnya politik internasional modern, yang oleh Scott diistilahkan sebagai Westphalian presumption, atau "anggapan Westphalia", yaitu suatu gagasan bahwa budaya dan plulralisme agama tidak boleh berada di ranah publik karena akan menimbulkan konflik dengan tatanan international. Karenanya, agama perlu diprivatisasi dengan cara dilembagakan, yang oleh Charles Taylor disebut sebagai "secular independent ethics" (etika bebas seculer), atau dengan cara digantikan dalam ranah public oleh suatu "etika kosmopolitanisme". Sistem Westphalia telah menetapkan sekularisme sebagai kode genetik dalam disiplin HI. Tujuannya untuk mengalihkan sekularisme kedalam suatu kondisi yang memungkinkan HI berkembang, daripada menjadi sebuah obyek dari penelitian.

Gambaran mengenai munculnya sistem negara-bangsa sekuler membawa tatanan yang terkandung didalamnya kekacauan agama ini, menandai dua hal: Pertama, negara yang bermunculan dibawah sistem Westphalia tidaklah sekuler, tetap lebih bersifat pengakuan. Ia berlandaskan pada sebuah proses berpindahnya hal-hal kesucian, yang telah membentuk keberadaan negara berdaulat ketika "Tuhan yang kekal yang para warganya berhutang perdamaian dan keamaan Tuhan.

Kedua, meskipun konflik antar kepercayaan di Eropa merupakan ekspresi ketidaksepakatan teologis, ia juga merupakan bagian dari strategi pembangunan bangsa yang didorong oleh para elit penguasanya yang memanfaatkan kapasitas tradisi agama untuk menimbulkan kohesi sosial dan untuk memobilisir kesetiaan dalam rangka memperkuat batasan antara komunitas agamis yang mampu bekerjasama dengan batasan negara.

Menurut William Cavanaugh, pandangan tradisional mengenai sistem internasional sangat mendukung terciptanya mitos kekerasa agama. Ini merupakan mitos pembenaran negara-bangsa liberal sebagai konsekuensi penafsiran dari nilainilai Pencerahan yang lebih besar, yang telah menemukan konsep dikotomi antara agamis dan sekuler dan menempatkan hal-hal agamis sebagai irrasional, impulsive dan membahayakan yang harus diberikan jalan di ranah public rasional, dalam bentuk kekuasaan sekuler.

Sejak itu, para pakar HI pun mulai mengakui bahwa telah terjadi adanya "prasangka sekuler" (secularist bias) baik di ranah publik maupun politik. Prasangka ini, dalam banyak hal, mengakibatkan gagalnya para pakar menempatkan agama dalam politik global. Selain itu, prasangka ini juga ikut berkonribusi terhadap rendahnya akurasi dan pemahaman para ahli mengenai peran agama dalam beragam kontek politik, termasuk dalam dunia Barat sekuler sendiri.

\section{Dikotom Modern dan Pra-Modern}

Terkait dengan modernisasi, sebagai bagian dari sekularisasi, konsep ini pun lahir di era Pencerahan (enlightenment) yang dianut antara lain oleh Voltaire, 
Montesquieu dan Diderot. Mereka sangat mengagungkan rasionalitas manusia yang dengan akal dan pengetahuan yang dimilikinya dapat membebaskan umat dari perbudakan oleh ikatan tradisi, utamanya oleh pihak Gereja. "Era Pencerahan melahirkan pandangan rasional mengenai dunia ini, yang didasarkan pada tolok ukur pembuktian empiris, iptek dan fenomena alam maupun penguasaan teknologi jagad raya. Modernisasi memasuki ranah publik melalui dua fenomena 'tantangan Kristianiti', yaitu munculnya kajian Ilmu Pasti dan faham demokrasi yang dimulai di Eropa pada Abad ke-17.

Revolusi Perancis, misalnya, targetnya bukan hanya terhadap kekuasaan raja tetapi juga lembaga Geraja sebagai rejim lain yang juga ikut membentuk tatanan masyarakat tradisional ketika itu. Konflik antara Gereja dan iptek telah berlangsung bahkan pada jauh-jauh hari sebelumnya ketika penemuan ilmu pasti, seperti yang dialami Galileo, memporakporandakan kepercayaan Gereja yang telah lama mengukuhi suatu kebenaran mutlak versinya sendiri. Iptek menjadi senjata dalam perjuangan suatu tertib sosial yang tidak didasarkan pada agama tetapi rasionalitas manusia semata

Menurut Thomas, modernisasi merupakan transformasi ekonomi, sosial, budaya dan infrastruktur politik yang lengkap dari negara-negara berkembang (the complete transformation of the economic, social, cultural, and political infrastructure of developing countries"). Hal ini secara politis telah menimbulkan adanya suatu dikotomi karakter masyarakat, yaitu yaitu yang modern dan pra-modern. Masyarakat pra-modern dianggap sebagai lawannya dari yang modern, bercirikan bahwa kesakralan tradisi diasumsikan sebagai pilar masyarakat yang tak tergoyahkan. Di dalamnya terkandung kesakralan agama, yang terinspirasi oleh tata nilai tertentu dan bersandarkan pada tradisi. Masyarakat seperti inilah yang ingin dirubah oleh para pendukung era Pencerahan untuk menjadi masyarakat yang rasional, berbasis iptek, HAM, perdagangan bebas dan sekuler, menuju terciptanya suatu tatanan dunia liberal dan menjadi tolok ukur modernitas bagi negara-negara yang masih belum berkembang.

Sangat jelas (obvious) bahwa karakter paling menonjol dari masyarakat modern adalah masyarakat yang sekuler, yang telah membuang pengaruh agama ke tempat tersendiri berdimensi pribadi. Menurunnya keberadaan agama di ranah publik dapat mendorong berkembangnya modernisasi hingga suatu tahapan ketika akhirnya agama musnah karena dirasakan tidak lagi bermanfaat dalam kehidupan masyarakat yang telah benar-benar modern.

Konsep modernisasi dan teori sekularisasi ini disetujui oleh para pakar sosial seperti Durkheim, Weber, Marc, Freud karena dianggap sebagai suatu kearifan konvensional dari masa awal kemunculan ilmu-ilmu sosial. Para ilmuwan sosial berharap bahwa ideologi sekuler, iptek dan rasionalisme dapat menjadi basis bagi kehidupan yang lebih baik di masyarakat modern, sama halnya seperti ketika agama berperan menjadi basis bagi masyarakat dan pemerintahan pada masa sebelumnya, yaitu pra-modern.

Ada suatu ironi yang tidak dapat diabaikan dalam membahas mengenai modernitas dan kebangkitan agama. Di tengah berbagai argument mengenai peran agama di masyakat ini, terdapat argument yang sangat ironis, bertentangan dengan 
alur pikir teori sekularisasi dan modernisasi. Intinya, modernisasi ternyata tidak menyebabkan punahnya agama namun justeru sebaliknya, ia menjadi penyebab bangkitnya kembali peran agama. Pandangan ini memiliki pijakan yang kuat karena melalui berbagai metode dan identifikasi berbagai proses di masyarakat. Begitu banyak bukti bahwa modernisasi ikut berperan terhadap kebangkitan agama, antara lain dapat dijelaskan sebagai berikut:

Pertama, di berbagai belahan Dunia Ketiga, upaya modernisasi telah gagal mengakibatkan perlawanan agamis terhadap ideology sekuler Barat yang menjadi dasar ideology pemerintahannya. Selain itu, akibat proses kolonialisme dan kolinialisme budaya, ide-ide sekuler Barat dipandang sebagai "makhluk asing", tidak memiliki dasar legitimasi, sehingga menyisakan agama lah yang memiliki kewenangan sebagai sumber legitimasi. Kedua, modernisasi meremehkan gaya perilaku (lifestylea) tradisional, nilai-nilai dan moral masyarakat yang sebenarnya merupakan bagian dari agama, sehingga membangkitkan penentangan agama terhadap modernitas.

Ketiga, modernisasi telah mengijinkan kelembagaan baik agama maupun negara untuk memperluas lingkup pengaruhnya sehingga mengakibatkan terjadinya konflik diantara keduanya Keempat, sistem politik modern memungkinkan partisipasi masa dalam politik sehingga menjadi saluran bagi unsur-unsur agamis masyarakat untuk dalam menyarakan pandangan terhadap pihak lain.

Kelima, komunikasi modern telah memungkinkan kelompok-kelompok keagamaan mengekspor pandangannya dengan mudah dan media internasional telah memungkinkan antar kelompok keagamaan saling memahami kegiatan mereka, yang kadang saling memberi inspirasi dan perbandingan satu sama lain. Keenam, kecenderungan baru dalam sosiologi agama, yang dikenal sebagai pilihan rasional atau teori ekonomi mengenai agama, menekankan bahwa kebebasan untuk memilih agamanya sendiri di banyak masyarakat telah mendorong pada meningkatnya halhal keagamaan.

Memang terlalu premature untuk mengatakan bahwa faham sekularisme telah mati, namun terdapat keraguan bila ia akan berkembang sebagaimana dibayangkan. Misalnya, terdapat pendapat umum bahwa kenyataannya proses modernisasi lah yang telah melahirkan kebangkitan kembali agama. Seperti dikatakan Samuel Huntington, "proses modernisasi ekonomi dan perubahan sosial di seluruh belahan dunia telah memisahkan masyarakat dari identitas lokal yang telah lama dianutnya. Selain itu, proses tersebut juga telah melemahkan keberadaan negara-bangsa sebagai sumber identitas. Di banyak bagian dunia, agama bergerak masuk mengisi kesenjangan ini, bahkan seringkali dalam bentuk gerakan yang dicap sebagai fundamentalis.

Tentu saja terdapat pertentangan mengenai dua pandangan antara, di satu pihak agama dianggap sebagai artifak peninggalan masa lalu yang semakin tidak relevan, dan di lain pihak ia dipandang sebagai terus menjadi sumber potensial konflik internasional. Bila asumsi hubungan antara agama dan perang memang benar, terdapat tiga hal yang perlu dipertanyakan: 
- Pertama, seharusnya terjadi penurunan jumlah penganut agama ketika dunia semakin bertambah damai.

- Kedua, dalam sudut pandang peperangan yang terjadi, seharusya tidak ada hubungannya dengan keencerungan bahwa mereka memiliki ragam agama yang berbeda yang kadang saling berselisih.

- Ketiga, bukti terkuat bagi faham sekularisasi akan mengalami penurunan dalam jumlah perang yang dilakukan atas nama agama.

Ketidakmampuan teori HI untuk memprediksi terjadinya berbagai peristiwa terkait dengan konotasi keterlibatan agama seperti "serangan 11 September, 2001, disertai respon terkejut dan tidak percaya khalayak maupun para politisi dan pimpinan negara di Barat menandakan adanya sesuatu yang salah dari para pakar $\mathrm{HI}$ dalam melakukan pendekatan terhadap politik global umumnya dan masalah agama khususnya. Reaksi kalangan akademik pun terlihat beragam. Beberapa berpendapat bahwa dunia telah mengalami perubahan yang drastis_sementara lainnya menganggap bahwa dunia tidak berubah. Sangat mengherankan bahwa dalam merespon berbagai peristiwa tersebut para ahli kemudian mempertanyakan mengenai peran agama, yang sebenarnya sudah sangat jelas dan tidak perlu diragukan. Peristiwa 11 September telah memberikan peringatan lebih dari peristiwa manapun dalam sejarah, bahwa agama memang tetap berperan sebagai suatu kekuatan besar dalam global politik, namun saat ini belum difahami secara utuh oleh para pakar dan praktisi HI.

Tidak bisa dielakkan bahwa telah terjadi 'kelemahan dan ketidak-akuratan' pada model analisis sekuler sehingga berbagai pendekatan terhadap masalah agama dan pengaruhnya dalam politik pun begitu meluas. Sebagian besar kesalahan ini disebabkan karena hingga sepuluh tahun terakhir, bahasan mengenai keberadaan agama tidak memberi perhatian yang cukup terhadap perannya dalam politik di negara-negara Barat serta dampaknya terhadap tindakan dan kebijakan mereka dalam politik global. Ketidak-perdulian terhadap agama dalam politik negara-negara Barat menyebabkan kesulitan untuk memahami peran agama dalam HI dan politik global pada umumnya. Karenanya, upaya mengkaji peran agama terhadap politk Barat sudah waktunya diakukan saat ini.

\section{B. PENUTUP}

Peran agama dalam kajian ilmu sosial umumnya dan HI khususnya merupakan suatu paradok yang menarik. Di satu pihak agama merupakan elemen penting dari sejarah kelahiran ilmu sosial, namun di lain pihak hingga kini agama tetap disingkirkan keberadaannya dalam kajian. Lebih khusus lagi, disiplin ilmu HI justeru telah dibangun atas dasar penolakan terhadap peran agama sebagai pedoman untuk memahami masyarakat. Para ilmuwan sosial berharap bahwa ideologi sekuler, pengetahuan dan rasionalisme yang mereka anut dapat memberikan suatu landasan bagi kehidupan yang lebih baik di era modern, seperti halnya yang diperankan oleh agama di era pra-modern masa lalu.

Penolakan terhadap agama didasari oleh pemikiran di atas. Pada beberapa disipllin limu, seperti sosiologi, menerapkan sikap tidak begitu ketat dalam menolak keberadaan agama. Namun tidaki demikian dengan disiplin HI. Agama ditiadakan dimarginalkan dalam setiap kajian sejak kelahirannya sehingga diibaratkan agama 
diasingkan dari dunia nyata milik HI. Tentu saja, kecenderungan meniadakan agama berpangkal pada karakter kajian HI terfokus pada Barat.

Teori HI sendiri adalah merupakan disiplin ilmu yang paling kuat meniadakan agama. Hal ini terlihat pada cara pandangnya yang selalu berorientasi Barat. Padahal jika diamati dengan lebih jeli sepanjang sejarah, dalam beragam peristiwa berskala internasional selalu terlihat bahwa agama menjadi salah satu faktor penting yang sering muncul antara lain menjadi bagian dari bentuk nasionalisme. Dalam banyak hal, nasionalisme ini memiliki banyak kesamaan dengan agama.

Sementara unsur-unsur sekularisasi tetap bercokol dengan pengaruhnya, terlihat kenyataan bahwa secara internal pandangan mereka tidak konsisten. Di hampir seluruh belahan dunia, dan hampir sepanjang keberadaan sejarah, penetrasi agama sangat dirasakan sehingga kebangkitannya kembali yang dihebohkan sekarang ini lebih tepat disebut sebagai kembali dari tempat pengasingannya.

Belum didapatnya kesepahaman mengenai bagaimana melibatkan agama dalam kajian HI. Apakah diperlukan munculnya paradigm baru ataukah memasukkannya ke dalam metodologi dan sitem kajian HI yang ada, menjadi bahan perdebatan hingga kini. Perdebatan ini diperkirakan akan terus berlanjut di kalangan para ahli HI dan mewarnai kajian HI ke depan. Tidak tertutup kemungkinan bahwa konsep negarabangsa sebagai bagian dari sistem Westphalia kemudian dipertanyakan, sebagai unit politik yang berlaku saat ini.

\section{DAFTAR REFERENSI}

Appleby, R. Scott, Religious Fundamentalisms and Global Conflict, New York: Foreign Policy Association Headline Series \#301, 1994, 7-8. Lihat juga : Shupe, Anson "The Stubborn Persistence of Religion in the Global Arena" in Emile Sahliyeh ed. Religious Resurgence and Politics in the Contemporary World, New York: State University of New York Press, 1990, hal.19

Turner, Brian S. Religion and Social Theory, 2nd ed., London: Sage, 1991, hal. 190-193

Pabst, 'The Secularism of Post-Secularity'

Lihat: Jeffrey Haynes, Religion, Politics and International Relations: Selected Essays (London: Routledge, 2011); Monica Duffy Toft, Daniel Philpott, and Timothy Samuel Shah (eds), God's Century: Resurgent Religion and Global Politics (New York: W. W. Norton \& Co., 2011); Jack Snyder (ed.), Religion and International Relations Theory (New York: Columbia University Press, 2011); Nukhet A. Sandal and Patrick James, 'Religion and International Relations Theory: Towards a Mutual Understanding', European Journal of International Relations, 17:3 (2011), pp. 3-25; Mona Kanwal Sheikh, 'How does Religion Matter? Pathways to Religion in International Relations', Review of International Studies, 38:2 (2012), pp. 36592.

Elizabeth Shakman Hurd, 'International Politics after Secularism'. dalam Review of International Studies, Volume 38, „Cambridge University Press, December 2012

Timothy Samuel Shah, "Introduction: Religion and World Affairs: Blurring the Boundaries" dalam Timothy Samuel Shah, Alfred Stepan, and Monica Duffy Toft, eds.,

Monica Duffy Toft, "Religion and International Relations Theory," dalam Handbook of International Relations (Oxford: Oxford University Press, 2012), 673.

Baird, Robert (1968). Interpretative Categories and the History of Religions. History and Theory 8 : 1968, hal.17-30.

Pummer, Reinhard, The Samaritans: A Profile, Library of Congress Cataloging in Publication Data, USA, 2016 
Jonathan Fox, Religion as an Overlooked Element in International Relations," International Studies Review, 3 (3), Fall 2001, 53-73. Definisi serupa dapat ditemukan dalam: Daniel Philpott, "The Challenge of September 11 to Secularism in International Relations," World Politics 55, no. 1 (October 2002):69

Rodney Stark, “Secularization, R.I.P.," Sociology of Religion, vol. 60, no. 3 (1999): 251. Also see Philpott, "The Challenge of September 11 to Secularism in International Relations," 81.

Jose Casanova, "Rethinking Public Religions" in Shah, Stepan, and Toft, eds., Rethinking Religion and World Affairs, 2012, hal. 25.

Jose Cassanova, Public Religions in the Modern World (Chicago: University of Chicago Press, 1994), mempermasalahkan validitas normative dan empiris mengenai pandangan privatisasi ini.

Secularization," The International Encyclopedia of Social and Behavioral Sciences, ed. Neil J. Smelser and Paul B. Baltes (Oxford: Elsevier, 2001) 13,786-91.

Fox, "Religion as an Overlooked Element in International Relations," hal. 54.

Jack Snyder, "Introduction" in Jack Snyder, ed., Religion and International Relations Theory, (New York: Columbia University Press, 2011), hal. 1.

Daniel Philpott, "Has the Study of Global Politics Found Religion?" Annual Review of Political Science 12 (2009): hal.186-87.

Kenneth D. Wald and Clyde Wilcox, "Getting Religion: Has Political Science Rediscovered the Faith Factor?", American Political Science Review, vol. 100, No. 4 (November 2006): hal. 526.

Philpott, "Has the Study of Global Politics Found Religion?" hal. 187.Juga lihat Bellin, "Faith in Politics: New Trends in the Study of Religion and Politics," 318; Michael Barnett, "Another Great Awakening? International Relations Theory and Religion" in Snyder, ed., Religion and International Relations Theory, hal. 91.

Daniel Philpott, “The Religious Roots of Modern International Relations,” World Politics, vol.52, No. 2 (January 2000): 213.

Cavanaugh, The Myth of Religious Violence, (New York: Oxford University Press, 2009), 123.

Elizabeth Shakman Hurd, The Politics of Secularism in International Relations (Princeton, NJ: Princeton University Press, 2008), 49.

Luca Mavelli, 'Security and Secularization in International Relations', European Journal of International Relations, 18:1 (2012), Hal. 177-99, hal. 178.

Hatzopoulos and Petito, 'The Return from Exile', hal. 1.

Mavelli, 'Security and Secularization', hal. 182.

Cavanaugh, The Myth of Religious Violence, hal . 4.

J. Fox, Religion, Civilization and Civil War: 1945 Through the New Millennium. (Lanham: Lexington Books 2004); J. Fox, "Religion as an Overlooked Element of International Relations" International Studies Review, vol. 3 no. 3 (2001), hal 53-73

E.S. Hurd, The Politics of Secularism in International Relations, (Princeton: Princeton University Press, 2008); L.N. Leustean dan J. T. S. Madeley, "Religion, Politics and Law in the European Union: An Introduction" Religion State and Society, vol. 37, no. 1 (2009), pp3-18

Norris \& Inglehart, Sacred and Secular: Religion and Politics Worldwide (Cambridge Studies in Social Theory, Religion and Politics), 2004:7 1

Kurtz, Lester, Gods in the Global Village: The World's Religions in Sociological Perspective. Thousand Oaks, California: Pine Forge Press. 1995.

Thomas, Scott M. “Taking Religious and Cultural Pluralism Seriously: The Global Resurgence of Religion and the Transformation of International Society", Millennium, 29 (3), 2005, hal. 51.

Juergensmeyer, Mark "Sacrifice and Cosmic War" Terrorism and Political Violence, 3 (3), 1991, 101117.

Sahliyeh, Emile ed., Religious Resurgence and Politics in the Contemporary World, New York: State University of New York Press, 1990.

Shupe, Anson "The Stubborn Persistence of Religion in the Global Arena" in Emile Sahliyeh ed. Religious Resurgence and Politics in the Contemporary World, New York: State University of New York Press, 1990, hal.17-26.

Rubin, Barry "Religion and International Affairs" in Douglas Johnston and Cynthia Sampson eds. Religion, the Missing Dimension of Statecraft, Oxford: Oxford University Press, 1994, 20-34.

Shupe, Anson "The Stubborn Persistence of Religion in the Global Arena" in Emile Sahliyeh ed. Religious Resurgence and Politics in the Contemporary World, New York: State University of New York Press, 1990, hal.17-26.

Samuel Huntington, “The Clash of Civilizations?” Foreign Affairs, vol. 71, no. 3 (Summer 1993):26.

Barnett, "Another Great Awakening?" 93-94. 
John Mueller, Retreat from Doomsday: The Obsolescence of Major War (New York: Basic Books, 1989).

D. Philpott, "The Challenge of September 11 to Secularism in International Relations" World Politics vol. 55, no.1 (2002), hal. 66-95

J. Fox, Religion, Civilization and Civil War: 1945 Through the New Millennium. (Lanham: Lexington Books 2004); J. Fox, "Religion as an Overlooked Element of International Relations" International Studies Review, vol. 3 no. 3 (2001), hal. 53-73

See, for example, Hurd op cit 2008 as well as recent issues of Social Research (Vol. 76, Issue 4 2009) and Religion, State and Society (Vol. 37, Issue 1 2009) 